\title{
Differential Expression of LEF1 Isoforms in Adult Lymphoid and Myeloid Malignancies
}

\author{
Yetişkin Lenfoid ve Miyeloid Malignitelerde LEF1 İzoformlarının Farklı \\ Ekspresyonu
}

\author{
Sinem Fırtına ${ }^{1,2}$ (D), Özden Hatırnaz $\mathrm{Ng}^{3}$ (D), Yücel Erbilgin ${ }^{1}$ (D), İbrahim Haznedaroğlu ${ }^{4}$ (D), \\ Müge Sayitoğlu' ${ }^{1}$
}

\begin{abstract}
'Department of Genetics, Aziz Sancar Institute of Experimental Medicine, Istanbul University, Istanbul, Turkey 2Department of Bioinformatics and Genetics, Faculty of Engineering and Natural Sciences, Istinye University, Istanbul, Turkey ${ }^{3}$ Department of Medical Biology, Acibadem School of Medicine, Acibadem Mehmet Ali Aydinlar University, Istanbul, Turkey ${ }^{4}$ Department of Internal Medicine, Hematology Unit, Hacettepe University, Ankara, Turkey
\end{abstract}

ORCID ID: S.F. 0000-0002-3370-8545; Ö.H.N. 0000-0001-7728-6527; Y.E. 0000-0001-6969-6649; I.H. 0000-0001-8028-9462; M.S. 0000-0002-8648-213X

Cite this article as: Fırtına S, Hatırnaz Ng Ö, Erbilgin Y, Haznedaroğlu I, Sayitoğlu M. Differential expression of LEF1 isoforms in adult lymphoid and myeloid malignancies. Experimed 2021;11(3): 184-8.

\begin{abstract}
Objective: Lymphoid enhancer-binding factor-1 (LEF1) is one of the key regulators of lymphocyte proliferation and its aberrant expression is a prognostic factor for lymphoid or myeloid malignancies. In this study, we focused on the expression of LEF1 isoforms in several hematological malignancies and found tissue-specific differential expression for the full-length (FL)-LEF1 gene and its tumor suppressor ( $\triangle L E F 1)$ variant.
\end{abstract}

Material and Method: Fifty-three leukemia/lymphoma patients were included in this study. Diagnostic samples of "lymphoid group" patients: Chronic Lymphoblastic Leukemia (CLL) $(n=10)$, B-cell Acute Lymphoblastic Leukemia (B-ALL) $(n=9)$ and "myeloid group" patients: Chronic Myeloblastic Leukemia (CML) $(n=12)$, Acute Myeloid Leukemia (AML) $(n=13)$, and Multiple Myeloma (MM) $(n=9)$ were studied. Healthy bone marrow, peripheral blood cells, and CD34 positive cells were used as controls. Total $(T)$ and FL-LEF1 transcript levels were examined by using quantitative real-time polymerase chain reaction (qRT-PCR). T and FL-LEF1 mRNA ratios were also evaluated for calculation of $\triangle L E F 1$.

Results: LEF1 levels were significantly high in lymphoid malignancies, but MM and AML patients have decreased LEF1 levels. Although CLL patients have high FL-LEF1 levels, the ratio of the T/FL levels was significantly decreased.

Conclusion: LEF1 is a proliferation factor for lymphocytes and not only its differential overexpression but also the ratio of T/FL isoforms seem to accompany leukemia progress.

Keywords: LEF1, alternative splicing, lymphoid, myeloid, leukemia

\section{ÖZ}

Amaç: Lenfositlerin çoğalmasındaki önemli düzenleyicilerden biri olan lenfoid güçlendirici bağlama faktörü-1 (LEF1)'in anormal ekspresyonu, lenfoid veya miyeloid maligniteler için prognostik bir faktördür. Bu çalışmada, farklı LEF1 izoformlarının çeşitli hematolojik malignitelerdeki ekspresyonu incelenmiş ve tüm uzunluktaki $L E F 1$ (FL-LEF1) anlatımı ile tümör baskılayıcı özelliğe sahip kısa izoformu ( $\triangle L E F 1)$ için dokuya özgü farklılıklar tespit edilmiştir.

Gereç ve Yöntem: Çalışmaya 53 yetişkin lösemi/lenfoma hastasının tanı anı örnekleri dahil edilmiştir. Çalışmaya dahil edilen hastalar, "lenfoid grubu"; Kronik Lenfoblastik Lösemi (KLL) ( $n=10)$, B hücreli Akut Lenfoblastik Lösemi (B-ALL) ( $n=9)$ ve "miyeloid grubu"; Kronik Miyeloblastik Lösemi (KML) ( $n=12)$, Akut Miyeloid Lösemi (AML) $(n=13)$ ve Multipl Miyelom (MM) $(n=9)$ gruplarından oluşmaktadır. Sağlıklı kemik iliği, periferik kan hücreleri ve CD34 pozitif hücreler kontrol olarak kullanılmıştır. Total (T) ve FL-LEF1 transkript seviyeleri, gerçek zamanlı kantitatif polimeraz zincir reaksiyonu (qRT-PZR) ile incelenmiştir. T ve FL-LEF1 oranları da $\Delta$ LEF1 hesaplaması için değerlendirilmiştir.

Bulgular: $L E F 1$ 'in lenfoid malignitelerde anlamlı derecede yüksek olduğu, MM ve AML hastalarında ise LEF1 seviyelerinde azalma olduğu görülmüştür. KLL hastalarında FL-LEF1 seviyeleri yüksek olmasına rağmen, T/FL-LEF1 seviyelerinin önemli ölçüde azaldığı tespit edilmiştir.

Sonuç: $L E F 1$, lenfositler için bir çoğalma faktörüdür ve sadece aşırı ekspresyonu değil, aynı zamanda T/FL-LEF1 izoformlarının oranının da lösemi ilerlemesine eşlik ettiğini düşündürmektedir..

Anahtar Kelimeler: LEF1, alternatif kırpılma, lenfoid, miyeloid, lösemi 


\section{INTRODUCTION}

Lymphoid enhancer binding factor-1 (LEF1), a member of the regulatory proteins called high mobility group proteins, is one of the key regulators in the proliferation of lymphocytes $(1,2)$. LEF1 is a downstream target of the WNT pathway involved in regulating cellular proliferation, differentiation, and organ development (3). Deregulated LEF1 expression was observed in specific cancer types such as colon and prostate cancer or various hematological malignancies like acute lymphoblastic leukemia (ALL), Burkitt lymphoma (BL), and Chronic Lymphocytic Leukemia (CLL) (4-6).

LEF1 has different isoforms caused by alternative splicing and these alternative isoforms can change transcriptional activity (7). The full-length LEF1 (FL-LEF1) isoform derives from selective activation of a promoter that can bind to beta catenin, and the other short isoform of LEF1 ( $\triangle L E F 1)$, located within the intronic promoter of $L E F 1$ and acts as a dominant-negative isoform (8). FL-LEF1 is expressed in mitotically active cells and behaves as a growth-promoting isoform; $\triangle L E F 1$ uses an alternative translation start site and lacks exons 1 and 2, resulting from the loss of the beta catenin binding site and acts as an inhibitory isoform and suppresses cell growth (9). Different LEF1 isoforms are transcribed in harmony under normal circumstances. Studies have shown that aberrant LEF1 activity and differential expression patterns in different $L E F 1$ isoforms were important in leukemia development $(6,10)$. FL-LEF1 was shown as a pro-survival factor in B-cell CLL cells, expressing abundant LEF1, but the expression of LEF1 gene is much lower or absent in low-grade B-cell non-Hodgkin's lymphoma (NHL), suggesting differences in the activity of the $L E F$ genes/isoforms between different malignancies $(11,12)$.

Our previous study showed that pediatric T-cell and B-cell ALL patients have differential expression of LEF1 variants (13). Therefore, in this study, we focused on LEF1 isoforms' expression in a group of adult lymphoid and myeloid hematological malignancies and found tissue-specific differential expression for LEF1 gene variants.

\section{MATERIAL AND METHOD}

\section{Study Population}

Fifty-three newly diagnosed patients in the hematology clinics were enrolled in this study. Diagnostic samples of "lymphoid group" patients: CLL (4) ( $n=10)$, B-cell ALL $(n=9)$, and "myeloid group" patients: AML $(n=13)$, Chronic Myeloblastic Leukemia $(C M L)(n=12)$, and Multiple Myeloma (MM) $(n=9)$ patients were diagnosed according to WHO criteria (14) at Hacettepe University, Faculty of Medicine, Hematology Department. Twenty-six males and twenty-seven females with a mean age of 58.5 \pm 13.3 for the lymphoid group and $56.6 \pm 14.1$ for the myeloid group were selected. Diagnostic samples whose white blood cell (WBC) count was above $20 \times 10^{3} / \mu \mathrm{L}$ were included. Patients who received chemotherapy prior to the study were excluded. The control group comprised of the bone marrow samples of 10 healthy individuals, and the CD34 positive cells of nine healthy donors for allogeneic peripheral stem cell transplantation. Additionally, peripheral blood cells $(n=5)$ were also studied. The study was approved by Hacettepe University Ethics Boards and Commissions (Project number: LUT 10/45) and all patients and healthy individuals signed written informed consent.

\section{RNA Isolation and CDNA Synthesis}

Mononuclear cells were collected, and total RNA was isolated according to the manufacturer's instructions (Qiagen, Germany). RNA quantity was measured by Nanodrop (ND-1000, Nanodrop Technologies, Inc., USA). 1000 ng RNA was used for CDNA synthesis by using random primers $(20 \mu \mathrm{M}$, Roche Diagnostics, Germany).

\section{Quantitative Real-time Polymerase Chain Reaction (qRT-PCR) Analysis}

Total (T)-LEF and FL-LEF1 mRNA levels were determined in patients and controls by qRT-PCR. To measure the balance between the isoforms, the ratio of T-LEF1/FL-LEF1 was also calculated for each hematologic malignancy. The primer sequences of $L E F 1$ isoforms and the qRT-PCR protocol were shown previously (13). CYPA and BACT genes were used as housekeeping genes. All runs were performed twice and each sample was run in duplicate. qRT-PCR analyses were performed on LightCycler 480 (Roche Diagnostics).

\section{Statistical Analysis}

The $2^{-\Delta \Delta C t}$ method was used for relative quantification (15). Groups were compared by using the Mann-Whitney $\mathrm{U}$ test and $p$-value of $\leq 0.05$ was considered significant.

\section{RESULTS}

We determined both LEF1 isoforms' expression in control CD34 positive cells, bone marrow cells, and peripheral blood cells and showed LEF1 variants at variable levels. Each patient sample was evaluated for $T$ and FL-LEF1 expression levels. T-LEF1 including long and $\triangle L E F 1$ isoforms and T/FL LEF1 ratio gives us $\triangle L E F 1$ isoforms levels. The ratio of total LEF1/ FL LEF1 in the lymphoid group (CLL and ALL) and myeloid group (AML, CML, and MM) patients were also evaluated.

In general analysis, lymphoid group patients had aberrant FLLEF1 expression ( $\mathrm{p}=0.01)$, but T-LEF1 levels and the T/FL ratio were normal compared to healthy control samples. Myeloid group patients showed decreased T-LEF1 $(\mathrm{p}=0.0009)$ and FLLEF1 ( $p=0.003$ ) expression, but the T/FL ratio was found to be similar compared to the controls. When we compared leukemia groups, the myeloid leukemia patients showed significantly decreased T $(p=0.008)$ and FL-LEF1 $(p=0.004)$ expression compared to lymphoid leukemia patients, and this deregulated $\mathrm{T}$ and FL-LEF1 expression levels caused decreased T/FL ratio $(p=0.03)$ in these patients.

Although there is no significant difference in T-LEF1 expression, the oncogenic isoform FL-LEF1 showed increased expression $(p<0.0001)$ compared to healthy bone marrow and 
peripheral blood cells in CLL patients. The ratio of T/FL-LEF1 was also found to decrease in CLL patients $(p=0.002)$ (Figure 1). Differently from CLL patients, adult B-ALL patients showed increased total $(p=0.02)$ and FL-LEF1 $(p<0.001)$ expression levels (Figure 1).

T-LEF-1 and FL-LEF1 mRNA expression levels were found to be significantly decreased in AML patients compared to CD34 positive healthy controls. In addition, the T/FL ratio was found to be similar when compared to the controls (Figure $2 \mathrm{~A}$ ). $\mathrm{CML}$ patients showed slightly decreased FL-LEF1 expression, but the ratio of T/FL-LEF1 was similar when compared to the controls (Figure 2).

The total expression levels of the $L E F 1$ gene and the ratio of $T /$ FL-LEF1 were found to be decreased in MM samples $(p=0.02$, $\mathrm{p}=0.02$, respectively) (Figure 2 ).

\section{DISCUSSION}

$L E F-1$ plays a role in the canonical Wnt signaling pathway by $\beta$-catenin and the LEF1/TCF complex, and activation of Wnt-target genes (16). Up-to-date studies point to activation of the
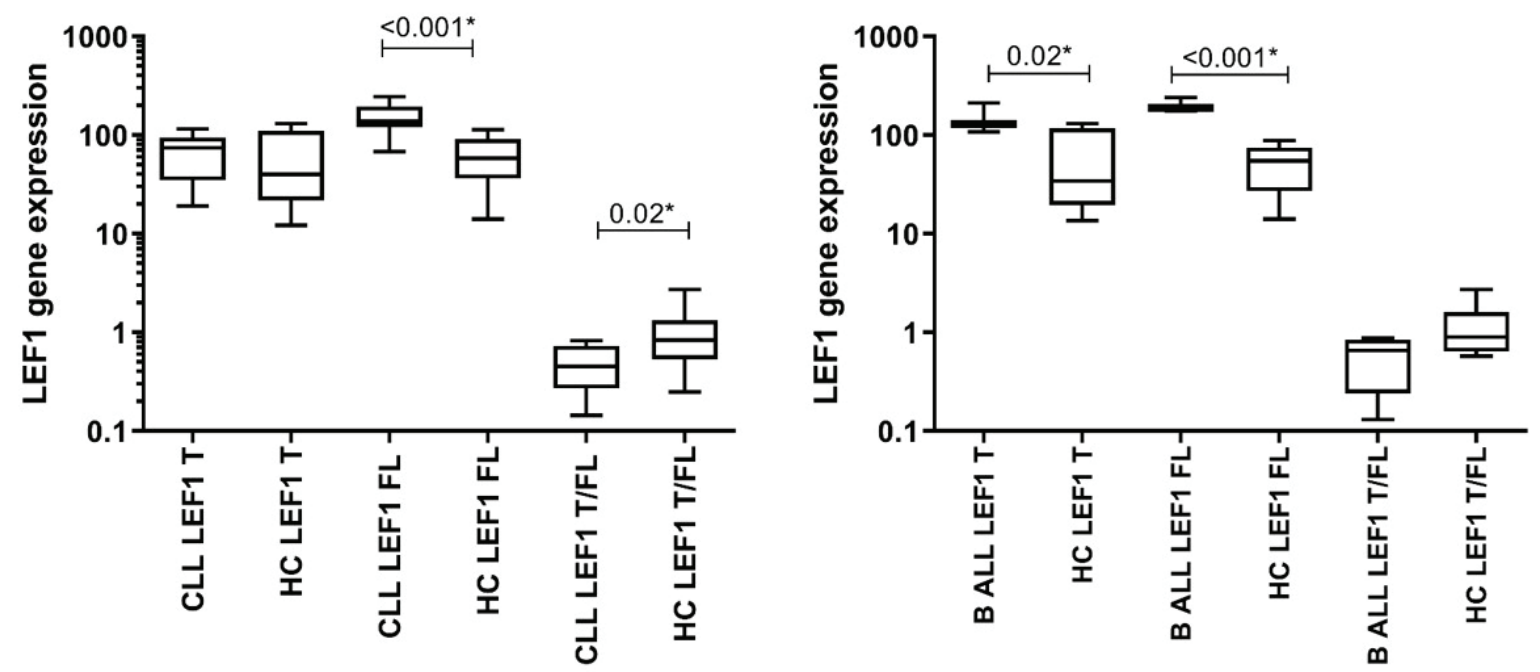

Figure 1. Expression analysis of $L E F 1$ isoforms in lymphoid group patients. $L E F 1$ expression in chronic lymphoblastic leukemia and adult B-cell acute lymphoblastic leukemia (B-ALL).

$T$ represents the total expression of $L E F 1$, FL represents full-length $L E F 1$ expression and T/FL represents the total and full-length ratio of LEF1 expression. T/FL ratio was used for calculating short ( $\triangle \mathrm{LEF1}$ ) isoform. CLL: Chronic Lymphoblastic Leukemia; B-ALL: Adult B-cell Acute Lymphoblastic Leukemia, HC: Healthy control sample. Statistical significance is shown by *
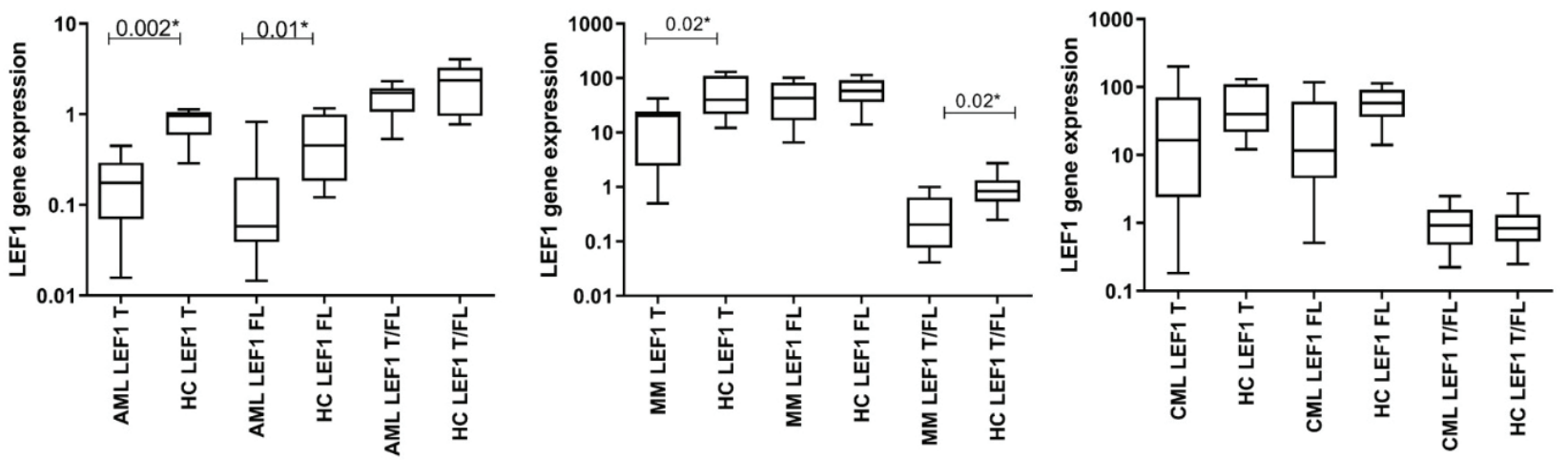

Figure 2. Expression analysis of LEF1 isoforms in myeloid group and multiple myeloma patients.

T represents the total expression of $L E F 1$, FL represents full-length $L E F 1$ expression and T/FL represents the total and full-length ratio of $L E F 1$ expression. T/FL ratio was used for calculating short ( $\triangle \mathrm{LEF} 1)$ isoform. AML: Acute Myeloid Leukemia; MM: Multiple Myeloma; CML: Chronic Myeloid Leukemia; HC: Healthy control sample. Statistical significance is shown by *. 
WNT pathway, and increased LEF1 expression as being associated with the pathogenesis of different leukemia types (17-21). Not only high LEF1 expression levels, but the existence of different isoforms and their heterogeneous contribution may also explain its role in malignancy development. The imbalance between the LEF1 isoforms was shown in the transformation of malignancies $(22,23)$. The role of the LEF1 gene in cell growth is not restricted upon the WNT pathway; studies have shown that $\triangle L E F 1$ stimulates the TCR alpha enhancer as strongly as FL-LEF1, which indicates that beta catenin has independent transactivation of the LEF1 gene (24). In human CD34 positive cells, inhibition of $F L-L E F 1$, but not beta catenin, affects proliferation and apoptosis of these progenitor cell populations, which supports that WNT is an independent function of LEF1 in early hematopoiesis (25).

In our previous study, we showed that pediatric ALL patients have increased FL-LEF1 expression and an abnormal ratio of long and short LEF1 isoforms have been found in $B$ and $T$ cell ALL (13). Here we defined the different expression patterns of LEF1 isoforms among adult lymphoid and myeloid malignancies and showed that although lymphoid and myeloid malignancies had significantly increased LEF1 expression, lymphoid group patients have significantly aberrant LEF1 activity according to the myeloid patients' group. We also further compared the lymphoid and the myeloid cohort and found that myeloid patients (including $A M L, C M L$, and $M M$ ) have decreased T-LEF1 expression levels. These results indicate that although imbalanced LEF1 isoforms were seen in both lymphoid and myeloid series, LEF1 activation is more related to lymphoid leukemia.

Guiterrez et. al reported LEF-1 expression in B-cell lymphocytosis previously (11). Recently, we have established that LEF1 is a highly specific marker for the diagnosis of B-CLL (26) and/ or LEF1 expression is related to atypical CLL (27). In our study, CLL cases showed differences in oncogenic FL-LEF1 and $\triangle L E F 1$ variants leading to the instability between long and short transcript ratio. These findings indicate that $L E F 1$ oncogenic activity might have a role in CLL but due to the limited number of CLL patients, our results did not show any subtype differences.

Adult B-ALL patients have upregulated total and FL-LEF1 isoforms, but the T/FL ratio was not changed indicating that the upregulation of T-LEF1 expression is related to high FL-LEF1 expression. Kühnl et al., identified that high LEF1 expression is a prognostic factor for adult B- ALL patients, and high LEF1 levels were associated with the outcome of the patients (28). While full length $L E F 1$ acts as an oncogene, a short transcript of the LEF1 gene functions as a tumor suppressor (29). Our results showed that adult B-ALL patients have increased FL-LEF1 isoform expression beside high $\triangle L E F 1$ isoform and the balance of T/FL-LEF1 were not changed.

In addition to the lymphoid group patients, our CML patients have unaffected $L E F 1$ gene expression and $L E F 1$ variant ratios. CML is a type of cancer resulting mostly from a reciprocal translocation $\mathrm{t}(9 ; 22)(\mathrm{q} 34 ; \mathrm{q} 11)$, which caused the accumulation of an active fusion kinase protein called BCR-ABL. The oncogenic role of $B C R-A B L$ is the dominant causative genetic defect in adult CML patients, but the WNT pathway activity is associated with tyrosine kinase inhibitory resistance and acute blast phase in leukemic stem cells in CML (30). Further studies are needed to understand the role of the $L E F 1$ gene in CML patients.

Unlike CML patients, multiple myeloma patients have decreased T-LEF1 expression, resulting in an abnormal T/FL-LEF1 isoform ratio, but no change in FL-LEF1 expression. These findings point to a reduced T/FL-LEF1 ratio occurring by impaired $\triangle L E F 1$ levels. In addition, $A M L$ patients showed decreased total and $F L-L E F 1$ and a slightly decreased level in $\triangle L E F 1$ expression. Recent studies reported that abnormal $\triangle L E F 1$ levels, but normal FL-LEF1 levels, were found in AML patients (31). Our results showed MM patients have similar results compared to AML patients in the literature.

In conclusion, we reported the LEF1 isoform levels in adult lymphoid and myeloid leukemia patients and observed impaired full-length or $\triangle L E F 1$ expression. Our results point to aberrant $L E F 1$ expression is mostly associated with lymphoid leukemia.

Acknowledgment: We would like to thank Suzin Catal Tatonyan for the support of laboratory studies.

Ethics Committee Approval: The study was approved by Hacettepe University Ethics Boards and Commissions (Project number: LUT 10/45) and all patients and healthy individuals signed written informed consent.

Peer-review: Externally peer-reviewed.

Author Contributions: Conception/Design of Study - S.F., Ö.H.N., Y.E., I.H., M.S; Materials - S.F., Ö.H.N., Y.E., I.H., M.S.; Data Collection - S.F., Ö.H.N., Y.E., I.H., M.S.; Analysis and/or Interpretation - S.F., Ö.H.N., Y.E., I.H., M.S.; Drafting Manuscript - S.F., Ö.H.N., Y.E., I.H., M.S.; Final Approval and Accountability - S.F., Ö.H.N., Y.E., İ.H., M.S.

Conflict of Interest: The authors have no conflict of interest to declare.

Financial Disclosure: This work was supported by the Scientific and Technological Research Council of Turkey (TUBITAK, Project No: 106S112).

Teşekkür: Laboratuvar çalışmalarında verdiği destek için Suzin Çatal Tatonyan'a teşekkür ederiz.

Etik Komite Onayı: Çalışma Hacettepe Üniversitesi Etik Kurulları tarafınca onaylanmış (Proje numarası: LUT 10/45) ve tüm hastalar ve sağlıklı bireylerden yazılı bilgilendirilmiş onam alınmıştır.

Yazar Katkıları: Çalışma Konsepti/Tasarımı - S.F., Ö.H.N., Y.E., I.H., M.S.; Materyal: S.F., Ö.H.N., Y.E., I.H., M.S.; Veri Toplama - S.F., Ö.H.N., Y.E., I.H., M.S.; Veri Analizi/Yorumlama - S.F., Ö.H.N., Y.E., İ.H., M.S.; Yazma - S.F., Ö.H.N., Y.E., I.H., M.S.; Son Onay ve Sorumluluk - S.F., Ö.H.N., Y.E., I.H., M.S.

Çıkar Çatışması: Yazarlar çıkar çatışması bildirmemişlerdir.

Finansal Destek: Bu çalışma Türkiye Bilimsel ve Teknolojik Araştırma Kurumu (TÜBITAK Proje no: 106S112) tarafından desteklenmiştir. 


\section{REFERENCES}

1. Reya T, O'Riordan M, Okamura R, Devaney E, Willert K, Nusse R, et al. Wnt signaling regulates $B$ lymphocyte proliferation through a LEF-1 dependent mechanism. Immunity 2000; 13: 15-24. [CrossRef]

2. Asally $\mathrm{M}$, Yoneda $\mathrm{Y}$. Beta-catenin can act as a nuclear import receptor for its partner transcription factor, lymphocyte enhancer factor-1 (lef-1). Exp Cell Res 2005; 308: 357-63. [CrossRef]

3. Santiago L, Daniels G, Wang D, Deng FM, Lee P. Wnt signaling pathway protein LEF1 in cancer, as a biomarker for prognosis and a target for treatment. Am J Cancer Res 2017; 7: 1389-406.

4. Sutton LA, Ljungström V, Enjuanes A, Cortese D, Skaftason A, Tausch $E$, et al. Comparative analysis of targeted next-generation sequencing panels for the detection of gene mutations in chronic lymphocytic leukemia: an ERIC multi-center study. Haematologica 2021; 106: 682-91. [CrossRef]

5. Morgan RG, Ridsdale J, Payne M, Heesom KJ, Wilson MC, Davidson $A$, et al. LEF-1 drives aberrant beta-catenin nuclear localization in myeloid leukemia cells. Haematologica 2019; 104: 1365-77. [CrossRef]

6. Petropoulos K, Arseni N, Schessl C, Stadler CR, Rawat VP, Deshpande $\mathrm{AJ}$, et al. A novel role for Lef-1, a central transcription mediator of Wnt signaling, in leukemogenesis. J Exp Med 2008; 205: 515-22. [CrossRef]

7. Hovanes K, Li TW, Munguia JE, Truong T, Milovanovic T, Lawrence Marsh J, et al. Beta-catenin-sensitive isoforms of lymphoid enhancer factor-1 are selectively expressed in colon cancer. Nat Genet 2001; 28: 53-7. [CrossRef]

8. Atcha FA, Munguia JE, Li TW, Hovanes K, Waterman ML. A new beta-catenin-dependent activation domain in T cell factor. J Biol Chem 2003; 278: 16169-75. [CrossRef]

9. Hovanes K, Li TW, Waterman ML. The human LEF-1 gene contains a promoter preferentially active in lymphocytes and encodes multiple isoforms derived from alternative splicing. Nucleic Acids Res 2000; 28: 1994-2003. [CrossRef]

10. Metzeler KH, Heilmeier B, Edmaier KE, Rawat VP, Dufour A, Dohner $\mathrm{K}$, et al. High expression of lymphoid enhancer-binding factor-1 (LEF1) is a novel favorable prognostic factor in cytogenetically normal acute myeloid leukemia. Blood 2012; 120: 2118-26. [CrossRef]

11. Gutierrez A, Jr., Tschumper RC, Wu X, Shanafelt TD, Eckel-Passow J, Huddleston PM, 3rd, et al. LEF-1 is a prosurvival factor in chronic lymphocytic leukemia and is expressed in the preleukemic state of monoclonal B-cell lymphocytosis. Blood 2010; 116: 2975-83. [CrossRef]

12. Seke Etet PF, Vecchio L, Nwabo Kamdje AH. Interactions between bone marrow stromal microenvironment and B-chronic lymphocytic leukemia cells: any role for Notch, Wnt and Hh signaling pathways? Cell Signal 2012; 24: 1433-43. [CrossRef]

13. Erbilgin $\mathrm{Y}$, Hatirnaz $\mathrm{Ng} \mathrm{O}$, Can I, Firtina S, Kucukcankurt F, Karaman $\mathrm{S}$, et al. Prognostic evidence of LEF1 isoforms in childhood acute lymphoblastic leukemia. Int J Lab Hematol 2021; 43(5): 10931103. [CrossRef]

14. Arber DA, Orazi A, Hasserjian R, Thiele J, Borowitz MJ, Le Beau MM, et al. The 2016 revision to the World Health Organization classification of myeloid neoplasms and acute leukemia. Blood 2016; 127: 2391-405. [CrossRef]

15. Livak KJ, Schmittgen TD. Analysis of relative gene expression data using real-time quantitative PCR and the 2(-Delta Delta $C(T)$ ) Method. Methods 2001; 25: 402-8. [CrossRef]
16. Danek P, Kardosova M, Janeckova L, Karkoulia E, Vanickova K, Fabisik $M$, et al. beta-Catenin-TCF/LEF signaling promotes steadystate and emergency granulopoiesis via G-CSF receptor upregulation. Blood 2020; 136: 2574-87. [CrossRef]

17. Guo X, Zhang R, Liu J, Li M, Song C, Dovat S, et al. Characterization of LEF1 High Expression and Novel Mutations in Adult Acute Lymphoblastic Leukemia. PLoS One 2015; 10: e0125429. [CrossRef]

18. Lyapichev KA, Sakhdari A, Khoury JD, O'Malley DP, El Hussein S, Yin $\mathrm{CC}$, et al. Lymphoid enhancer binding factor 1 (LEF1) expression is significantly higher in Hodgkin lymphoma associated with Richter syndrome relative to de novo classic Hodgkin lymphoma. Ann Diagn Pathol 2020; 49: 151636. [CrossRef]

19. Xu R, Huang X, Li C, Deng C, Li M, Wu P, et al. Bone marrow mesenchymal stromal cells in chronic myelomonocytic leukaemia: overactivated WNT/beta-catenin signalling by parallel RNA sequencing and dysfunctional phenotypes. Br J Haematol 2021; 193: 928-40. [CrossRef]

20. $\mathrm{Ng} \mathrm{OH}$, Erbilgin Y, Firtina S, Celkan T, Karakas Z, Aydogan G, et al. Deregulated WNT signaling in childhood T-cell acute lymphoblastic leukemia. Blood Cancer J 2014; 4: e192. [CrossRef]

21. Fetisov TI, Lesovaya EA, Yakubovskaya MG, Kirsanov KI, Belitsky GA. Alterations in WNT Signaling in Leukemias. Biochemistry (Mosc) 2018; 83: 1448-58. [CrossRef]

22. Jimenez J, Jang GM, Semler BL, Waterman ML. An internal ribosome entry site mediates translation of lymphoid enhancer factor-1. RNA 2005; 11: 1385-99. [CrossRef]

23. Li TW, Ting JH, Yokoyama NN, Bernstein A, van de Wetering M, Waterman ML. Wnt activation and alternative promoter repression of LEF1 in colon cancer. Mol Cell Biol 2006; 26: 5284-99. [CrossRef]

24. Hsu SC, Galceran J, Grosschedl R. Modulation of transcriptional regulation by LEF-1 in response to Wnt-1 signaling and association with beta-catenin. Mol Cell Biol 1998; 18: 4807-18. [CrossRef]

25. Skokowa J, Cario G, Uenalan M, Schambach A, Germeshausen M, Battmer K, et al. LEF-1 is crucial for neutrophil granulocytopoiesis and its expression is severely reduced in congenital neutropenia. Nat Med 2006; 12: 1191-7. [CrossRef]

26. Menter T, Trivedi P, Ahmad R, Flora R, Dirnhofer S, Tzankov A, et al. Diagnostic Utility of Lymphoid Enhancer Binding Factor $1 \mathrm{~lm}$ munohistochemistry in Small B-Cell Lymphomas. Am J Clin Pathol 2017; 147: 292-300. [CrossRef]

27. Soliman DS, Al-Kuwari E, Siveen KS, Al-Abdulla R, Chandra P, Yassin $M$, et al. Downregulation of Lymphoid enhancer-binding factor 1 (LEF-1) expression (by immunohistochemistry and/ flow cytometry) in chronic Lymphocytic Leukemia with atypical immunophenotypic and cytologic features. Int J Lab Hematol 2021; 43: 515-25. [CrossRef]

28. Kuhnl A, Gokbuget N, Kaiser M, Schlee C, Stroux A, Burmeister T, et al. Overexpression of LEF1 predicts unfavorable outcome in adult patients with B-precursor acute lymphoblastic leukemia. Blood 2011; 118: 6362-7. [CrossRef]

29. Yokoyama NN, Pate KT, Sprowl S, Waterman ML. A role for YY1 in repression of dominant negative LEF-1 expression in colon cancer. Nucleic Acids Res 2010; 38: 6375-88. [CrossRef]

30. Masamoto $Y$, Kurokawa M. Targeting chronic myeloid leukemia stem cells: can transcriptional program be a druggable target for cancers? Stem Cell Investig 2018; 5:10. [CrossRef]

31. Feder K, Edmaier-Schroger K, Rawat VPS, Kirsten N, Metzeler K, Kraus JM, et al. Differences in expression and function of LEF1 isoforms in normal versus leukemic hematopoiesis. Leukemia 2020; 34: 1027-37. [CrossRef] 